\title{
Giovanni Battista Della Porta's Experiments with Musical Instruments
}

\section{Rebecca Cypess}

To cite this article: Rebecca Cypess (2016) Giovanni Battista Della Porta's Experiments with Musical Instruments, Journal of Musicological Research, 35:3, 159-175, DOI: 10.1080/01411896.2016.1180946

To link to this article: https://doi.org/10.1080/01411896.2016.1180946

曲 Published online: 25 May 2016.

Submit your article to this journal $\pi$

Џ Article views: 99

Q View related articles ๘

View Crossmark data $[\pi$ 


\title{
Giovanni Battista Della Porta's Experiments with Musical Instruments
}

\author{
Rebecca Cypess \\ Rutgers, The State University of New Jersey
}

\begin{abstract}
A section of Giovanni Battista Della Porta's Magia naturalis (1589) celebrates the powers of musical instruments. Most of these powers are rooted in neo-Platonist natural magic: Della Porta explains that the materials of instruments retain their original properties, shaping the body and soul of the listener through their mutual sympathy or antipathy. In a series of three demonstrations presented at the end of this section on music, however, Della Porta uses musical instruments in a different fashion: like telescopes and other scientific instruments of the early modern era, his lyra-likely a lira da braccio, which held pride of place in Italian academies of the sixteenth century-becomes a vehicle for open-ended discovery and the creation of new knowledge.
\end{abstract}

Giovanni Battista Della Porta opened the expanded edition of his Magia naturalis (1589) by enumerating the virtues of magic as a component of natural philosophy, and by listing the many areas of expertise required of the magus. In order to understand the secrets of natural magic and to put them to use for the benefit of humanity, the magus must become a master philosopher, physician, herbalist, distiller, mathematician, astrologer, and optical scientist. To all this, moreover, the magus must add one more layer of knowledge:

He must be a skillful workman, both by natural gifts, and also by the practise of his own hands: for knowledge without practice and workmanship, and practice without knowledge, are nothing worth; these are so linked together, that the one without the other is but vain, and to no purpose. ${ }^{1}$

Recent work in art history, the history of science, and related fields has demonstrated the integral links between artisanship and the new approaches to the study of the natural world that emerged in the early seventeenth century. Theorists and philosophers including Galileo Gailei, Francis

Color versions of one or more of the figures in the article can be found online at www.tandfonline.com/gmur.

1"Sit Naturae dono artifex, \& mechanicus: nam sine artificio sciens, aut ignarus artifex (adeò coniuncta sunt) ut frustrà terat operam, nec optato potiatur unquam." Giovanni Battista Della Porta, Magiae naturalis libri XX (Naples: Horatium Salvianum, 1589), 3; translated as Natural Magick (London: Printed for Thomas Young and Samuel Speed, 1658), 3. All translations from Della Porta's treatise are taken from this source, and original spellings are retained. The only changes made to the Latin are in modifications of " $u$ "s that function as " $v$ " $s$ and vice versa. I refer to the Latin volume hereafter in short form as Magia naturalis, and to the English as Natural Magick.

(c) 2016 Taylor \& Francis 
Bacon, and René Descartes recognized the work of artisans at their instruments as essential for the formation of knowledge, and they saw the systematic methods of artisans as models for the organization of information in their new approach to the study of the world. Moreover, these seventeenth-century theorists came to see instruments-a category encompassing material tools, human sensory organs, and logical apparatus such as Bacon's Novum organum ("new instrument") - in new ways. Rather than viewing instruments merely as vehicles for the repetition of a process already known (for example, the instruments used by the blacksmith to make his wares), these thinkers saw instruments as tools to be used in the open-ended inquiry that would lead to new knowledge. The classic example of this new kind of instrumentality was Galileo's high-powered telescope, with which, as he explained in his Siderius nuncius (1610), he made the revolutionary discoveries that would unsettle the Aristotelian conception of the heavens. ${ }^{2}$

Della Porta's theories of natural magic, rooted in neo-Platonist ideas concerning the "sympathetic" workings of all objects in the world-animate and inanimate-seem quaint when compared with the writings of Bacon, Descartes, and especially Galileo, Della Porta's younger colleague in the Accademia dei Lincei. Yet within Della Porta's work, we can discern the beginnings of a rigorous, empirical approach to the study of the natural world, for the author asserted that he had tested all of the wisdom contained in that immense volume through experience and observation. Whether this claim was true in all cases is another matter (and one to which I will return below); of primary importance, however, is Della Porta's sense that the claim itself was a worthy one. ${ }^{3}$

\footnotetext{
${ }^{2}$ The literature on the relationship between artisanship and the arts and sciences in the early modern era is too extensive to list here, but some of the most important studies on these subjects are David Freedberg, The Eye of the Lynx: Galileo, His Friends, and the Beginnings of Modern Natural History (Chicago: University of Chicago Press, 2002); Pamela H. Smith, The Body of the Artisan: Art and Experience in the Scientific Revolution (Chicago: University of Chicago Press, 2004); and Smith, "Art, Science, and Visual Culture in Early Modern Europe," Isis 97/1 (March 2006), 83-100. On the conception of instruments in the seventeenth century, see Jean-François Gauvin, "Instruments of Knowledge," in The Oxford Handbook of Philosophy in Early Modern Europe, ed. Desmond M. Clarke and Catherine Wilson (Oxford: Oxford University Press, 2011), 315-37; Antoni Malet, "Early Conceptualizations of the Telescope as an Optical Instrument," Early Science and Medicine 10/2 (2005), 237-62; and J. Bennett, "Knowing and Doing in the Sixteenth Century: What Were Instruments for?" British Journal for the History of Science 36 (2003), 129-50. On Galileo's telescope and his ideas of instruments, see Horst Bredekamp, Galilei der Künstler: Der Mond. Die Sonne. Die Hand (Berlin: Akademie Verlag, 2007); Bredekamp, "Gazing Hands and Blind Spots: Galileo as Draftsman," in Galileo in Context, ed. Jürgen Renn (Cambridge: Cambridge University Press, 2001), 153-92; Mario Biagioli, Galileo's Instruments of Credit: Telescopes, Images, Secrecy (Chicago: University of Chicago Press, 2006); and Eileen Reeves, Painting the Heavens: Art and Science in the Age of Galileo (Princeton, NJ: Princeton University Press, 1997).

${ }^{3}$ Della Porta's theories of sympathy are laid out in the first book of his treatise, "Of the Causes of Wonderful Things." On the role of music in systems of natural magic, see Gary Tomlinson, Music in Renaissance Magic: Toward a Historiography of Others (Chicago: University of Chicago Press, 1993). Penelope Gouk has explored the relationship between musical instruments and natural magic, especially in English thought of the seventeenth century, in Penelope Gouk, Music, Science, and Natural Magic in Seventeenth-century England (New Haven, CT: Yale University Press, 1999), and more recently in "Music and the Emergence of Experimental Science in Early Modern Europe," SoundEffects 2/1 (2012), 6-21. On Della Porta's relationship to the Lincei, see Freedberg, The Eye of the Lynx, 72-75 and passim. On Della Porta's developments in lens technology and their relationship to Galileo's telescope, see Freedberg, The Eye of the Lynx, 101-105, and Eileen Reeves, Galileo's Glassworks: The Telescope and the Mirror (Cambridge, MA: Harvard University Press, 2009).
} 
Central to Della Porta's burgeoning empirical approach was the use of instruments of all sorts. The final chapter of the Magia naturalis, a miscellany of tricks and demonstrations subsumed under the title "Chaos," includes instructions for a handful of experiments using musical instruments. Primacy in experimentation with musical instruments-those exercises that laid the groundwork for the nascent field of acoustics-is normally ascribed to Vincenzo Galilei, father of Galileo. However, the handful of experiments with musical instruments laid out in Della Porta's volume-directed at an amateur readership of learned gentlemen and academicians-attests to the pursuit of acoustical knowledge among others of the same generation.

Della Porta's experiments with musical instruments warrant consideration for two reasons: first, they strengthen evidence of the links between the neoPlatonist systems of natural magic that informed late sixteenth-century thought and the methods of the new sciences of the seventeenth century. Second, these experiments shed new light on the culture of musical "instrumentality" in the early modern era. It was not until the second decade of the seventeenth century that composers began to write and publish a large repertoire of independent, idiomatic instrumental music-a repertoire that responded to the special properties and capabilities of specific instruments and that was largely unsuited, therefore, to performance using other instruments or human voices. Nevertheless, Della Porta's work indicates that instruments were already being used in innovative, exploratory, and idiomatic ways in unwritten traditions during this earlier period. Della Porta relied on an instrument that he called the lyra, which, as I will show, reflects the academic milieu in which he conducted his experiments. The few paragraphs that he devoted to acoustical magic demonstrate that he prefigured seventeenth-century theorists in understanding musical instruments as part of the larger category of tools and machines to be put to use in the quest for new knowledge. ${ }^{4}$

\section{Della Porta's acoustical experiments and the lira da braccio}

In his preface to the Magia naturalis, Della Porta defended his experiencebased approach. He claimed to have traveled across Europe and corresponded with learned men everywhere to collect information concerning the secrets of nature. But rather than accepting their testimony or the testimony of ancient authors about the effects of one material on another, or of an action by one human being on another, Della Porta asserted that he had evaluated this wisdom thoroughly through hands-on experience:

\footnotetext{
${ }^{4}$ For an exploration of the concept of instrumentality as it relates to the repertoire of Italian instrumental music from the 1610s through the 1630s, see Rebecca Cypess, Curious and Modern Inventions: Instrumental Music as Discovery in Galileo's Italy (Chicago: University of Chicago Press, 2016).
} 
Whatsoever was Notable, and to be desired through the whole World, for Curiosities and Excellent Things, I have abundantly found out, and therewith Beautified and Augmented these, my Endeavours, in NATURAL MAGICK, wherefore by most earnest Study, and constant Experience, I did both night and day endeavour to know whether what I heard or read, was true or false, that I might leave nothing unassayed. ${ }^{5}$

Citing Cicero, Della Porta affirmed he had decided to "make tryal of all things." To this end, he assembled "at my house an Academy of curious Men, who for the trying of these Experiments, chearfully disbursed their Moneys, and employed their utmost Endeavours, in assisting me to Compile and Enlarge this Volume." 6 To be sure, the term experientia in the sixteenth and seventeenth centuries had a flexible meaning, including both experimentation in the modern scientific sense and also simply experience, but the term nevertheless highlights the importance of sensory observation and empiricism in Della Porta's methods. Like a collector assembling curiosities for his Kunstkammer, Della Porta had sought out curiosities for his book. With his friends, he had assembled his own academy for the purpose of testing all of the secrets he had found, sorting truth from falsehood. ${ }^{7}$

Della Porta's intention, he wrote, was to assemble all of this information in recognizable categories. In the final book of the Magia naturalis, however, he admitted that there were some experiments that had resisted categorization. He introduced this final book, the "Chaos," by warning that its contents had been "set down without any Classical order." He explained,

Therefore I shut up in this Book, those Experiments that could be included in no Classes, which were so diverse and various, that they could not make up a Science, or a Book; and thereupon I have here heaped them altogether confusedly as what I had overpassed; and if God please, I will another time give you a more perfect book. Now you must rest content with these. ${ }^{8}$

\footnotetext{
${ }^{5 “}$ Universo hoc tempore quicquid tertarum ubiq; eximium erat, aut expetendum, tum librorum, tum praestantissimarum rerum mihi cumulatissimè conquisitum est, ut cumulatior, auctiorq'; Naturae haec supellex foret. Itaq; intensissimo studio, pertinaciq'; experientia, perdius, atq; per nox periclitabar quae legeram, vel audieram, vera ne essent, an falsa, ne intentatum aliquid remaneret." Della Porta, "Ad lectores praefatio," in Magia naturalis, [no page]; translated as "To the Reader," in Natural Magick, [no page].

${ }^{6}$ "Nec domi meae defuit unquam curiosorum hominum Academia, qui in his vestigandis, experiendisq'; collato aere strenuam alacremq'; operam navarent, quiq'; hoc opere concinnando." Della Porta, "Ad lectores praefatio," in Magia naturalis, [no page]; translated as "To the Reader," in Natural Magick, [no page].

${ }^{7}$ On the Italian cognate esperienza as used by Vincenzo Galilei, see Claude V. Palisca, "Was Galileo's Father an Experimental Scientist?" in Number to Sound: The Musical Way to the Scientific Revolution, ed. Paolo Gozza (Dordrecht, The Netherlands: Kluwer Academic, 2000), 191-99. On the significance of Kunstkammern for natural philosophy in the early modern era, see especially Horst Bredekamp, The Lure of Antiquity and the Cult of the Machine: The Kunstkammer and the Evolution of Nature, Art, and Technology, trans. Allison Brown (Princeton, NJ: Markus Wiener, 1995).

${ }^{8 "} \mathrm{Hoc}$ igitur libro ea experimenta clausimus, quae nullis classibus concludi poterant, quae aedò varia, \& diversa erant, ut non scientiam, aut librum conficere poterant, quae etiam quasi paralipomena huc coacervavimus, in chaos fortaße. Deo dan te aliàs perfectiorem dabimus librum. Nunc aut em his contenti eritis." Della Porta, Magia naturalis, 292; translated in Natural Magick, 395.
} 
Included in this "Chaos" are methods for the desalinization of water, for making stones appear to move on their own, for increasing the weight of various materials, and a wide array of other tricks. Within this chapter Della Porta also presented a number of acoustical wonders, which I would divide into three categories: the first is his design for an ear trumpet, which he likened to a pair of spectacles in its effect on the user. The second type of acoustical marvel consists of descriptions of the "sympathetic" resonance between sound and the physical or emotional properties of those who listen to it, characteristic of a neo-Platonist worldview; indeed, in this section Della Porta cited a long list of classical authors from whom this wisdom derived. Finally, although Della Porta did not distinguish this category himself, the last three wonders described in the section on acoustical "sympathies," which I will discuss further below, are clearly of another sort: rooted in demonstrable sensory observations, these three cases should be understood as experimental in nature. ${ }^{9}$

With the exception of his ear trumpet, Della Porta linked his acoustical experiments to one musical instrument in particular. Although the 1658 English translation of his work describes the wondrous properties of the "harp," this translation is not quite accurate-or, at least, it is ambiguous. The term that Della Porta used is lyra; and it is likely that by lyra he meant to refer to the lira da braccio ("arm lyre")-a bowed stringed instrument that reached the height of its popularity when the violin was still looked down on as low-class. Surviving exemplars of the lira da braccio indicate that different instruments were strung differently; whereas most included seven strings, they could hold anywhere from four to nine strings organized in a variety of tunings and dispositions. An apparently essential feature was the presence of at least one, but more often two, "drone" strings that ran along the side of the instrument to the left of the fingerboard. Because of its positioning, such strings could not be stopped with the fingers of the player's left hand and could therefore not be used to play a melody; instead, they were employed to create chords with the higher strings or to resonate sympathetically them. ${ }^{10}$

Chordal accompaniment involving the drone strings would have facilitated one of the primary uses of the lira da braccio in the sixteenth century: to accompany the recitation of epic poetry, performed all'improvviso. Musical-poetic performance of this sort was seen as essential to the character-building and education of Renaissance letterati, and Robert Nosow has shown that for this purpose the lira da braccio was the delight

\footnotetext{
${ }^{9}$ Della Porta, Magia naturalis, 298-300; translated in Natural Magick, 402-405.

${ }^{10}$ On the lira da braccio, see Sterling Scott Jones, The lira da braccio (Bloomington: Indiana University Press, 1995). On the status of the violin in this early stage, see Peter Holman, Four and Twenty Fiddlers: The Violin at the English Court, 1540-1690 (Oxford: Clarendon Press, 1995), ch. 1, "'Quagmires of History and Terminology': The Origin of the Violin"; David D. Boyden, The History of Violin Playing from Its Origins to 1761 and Its Relationship to the Violin and Violin Music (London: Oxford University Press, 1965).
} 
of Italian academies during the sixteenth century. Although we have a sense of how such recitations worked from contemporaneous accounts of academic and courtly gatherings, precious few written musical settings survive. $^{11}$

The lira da braccio was frequently pictured in artwork of the Renaissance in the hands of gods and kings; the image of Apollo holding a lira on Parnassus in Raphael's Stanze della segnatura at the Vatican (1510-11) is among the most famous of these depictions (see the detail shown in Figure 1). In the Allegory of Hearing (1617-18) that forms one of the five panels known as The Senses by Jan Brueghel the Elder and Peter Paul Rubens,

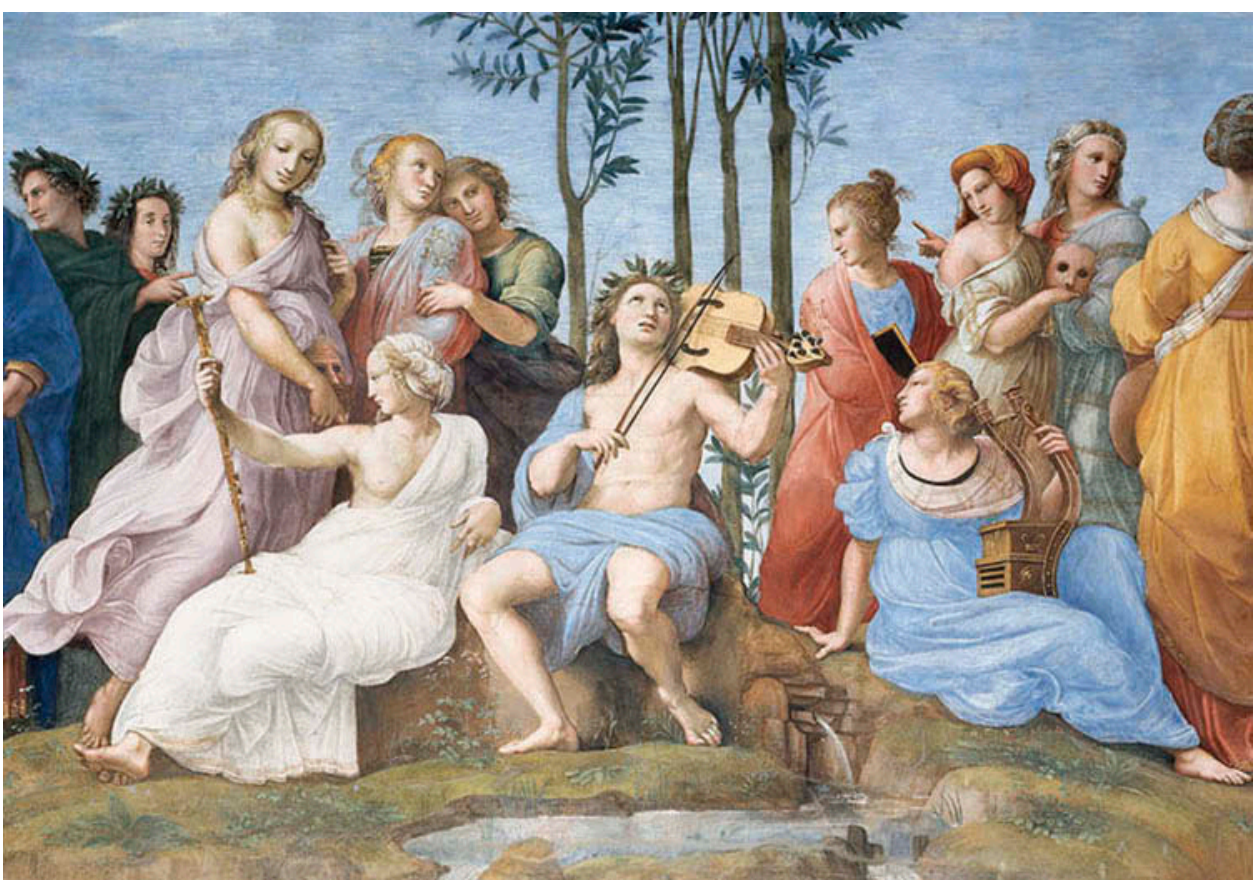

Figure 1. Raphael, Stanze della segnatura, detail. @ Scala/Art Resource, NY. Reproduced by permission of Scala/Art Resource, NY. Permission to reuse must be obtained from the rightsholder.

\footnotetext{
${ }^{11}$ On improvised musical-poetic recitation during the period, see Ivano Cavallini, "Sugli improvvisatori del CinqueSeicento: persistenza, nuovi repertori e qualche riconoscimento," Recercare1 (1989), 23-40, as well as James Haar, Essays on Italian Poetry and Music in the Renaissance (Berkeley: University of California Press, 1986), ch. 4, "Improvvisatori and Their Relationship to Sixteenth-century Music"; Nino Pirrotta, "New Glimpses of an Unwritten Tradition" and "The Oral and Written Traditions of Music," in Music and Culture in Italy from the Middle Ages to the Baroque (Cambridge, MA: Harvard University Press, 1984), 51-71 and 73-79, respectively; Margaret Murata, "Cantar ottave, cantar storie," in Word, Image, and Song, vol. 1: Essays on Early Modern Italy, ed. Rebecca Cypess, Beth L. Glixon, and Nathan Link (Rochester, NY: University of Rochester Press, 2013), 287-317; and Alfred Einstein, "Die Aria di Ruggiero," Sammelbände der Internationalen Musik-Gesellschaft 13 (1911-12), 444-54. On the use of the lira da braccio among noble letterati, see Stefano Lorenzetti, Musica e identità nobiliare nell'Italia del Rinascimento: educazione, mentalità, immaginario (Florence: Olschki, 2003), 83-90. On the use of the lira da braccio within Italian academies, see Robert Nosow, "The Debate on Song in the Accademia Fiorentina," Early Music History 21 (2002), 179-83. For a discussion of a seventeenth-century composition for violin that imitates (and therefore codifies) the performance practices of the lira da braccio, see Cypess, Curious and Modern Inventions, ch. 1 and ch. 5.
} 


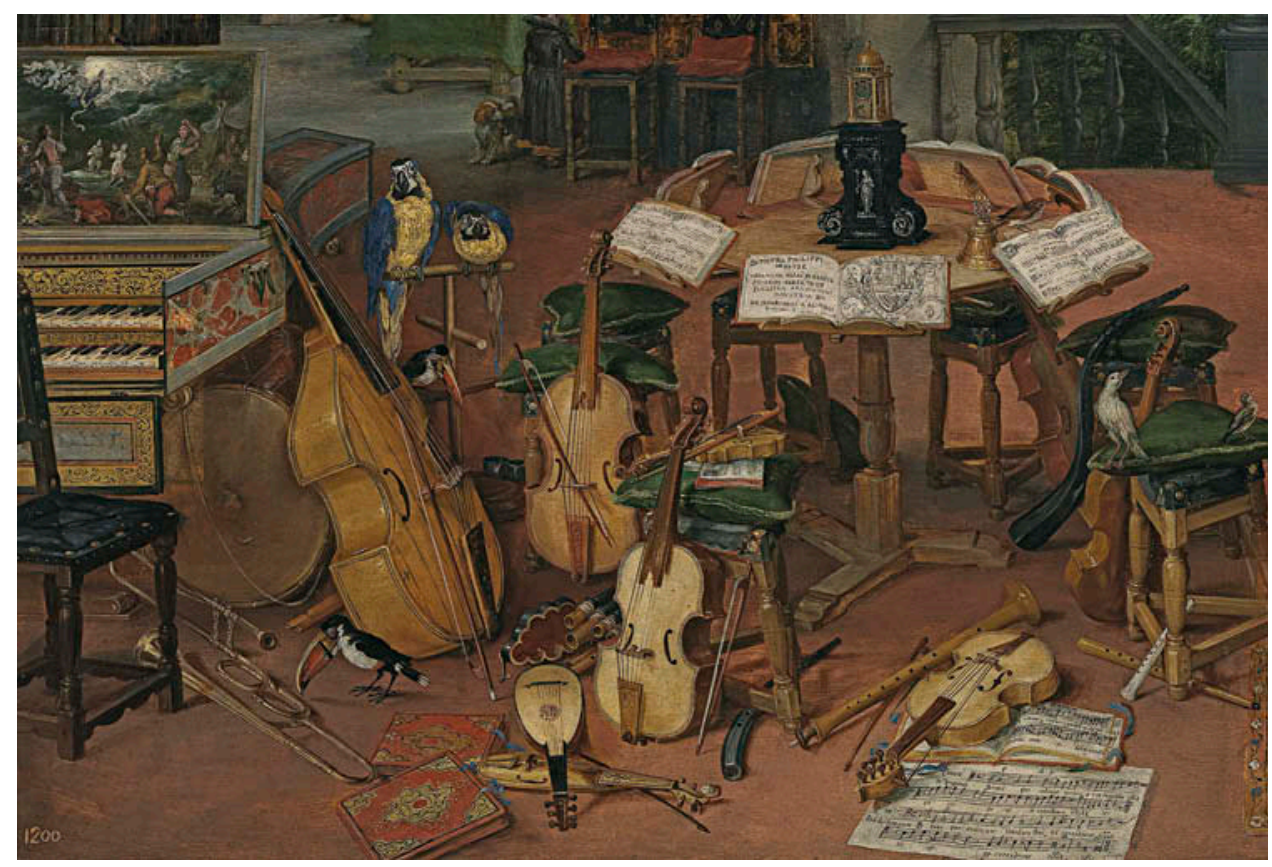

Figure 2. Jan Brueghel the Elder and Peter Paul Rubens, Allegory of Hearing, detail. ๑ Album/Art Resource, NY. Reproduced by permission of Album/Art Resource, NY. Permission to reuse must be obtained from the rightsholder.

a lira da braccio lies on the floor amid a Kunstkammer-like collection of musical and other sonic curiosities (see the instrument in the lower righthand corner of the detail shown in Figure 2). ${ }^{12}$

Considered against the backdrop of this musical culture within Italian academies, Della Porta's claim that he had tested all of his experiments within his academy takes on greater significance. With respect to his acoustical experiments, Della Porta's treatise offers a glimpse of the kinds of activities that would have occupied such learned groups, attesting to the close relationship among music, poetry, magic, and natural philosophy in early modern thought. Musical performance could easily transition to scientific performance: as the magus led his academy in the testing of his wonders of natural magic, he put into service a musical instrument that was likely readily available to them and to other letterati who might seek to replicate his acoustical experiments-the lyra.

Della Porta's neo-Platonist worldview led him to articulate, in the opening book of the Magia naturalis, the view that all materials in the world are connected to one another either through sympathy or antipathy; the wonders that he codified from classical sources and from folklore confirm that he was concerned with the

\footnotetext{
${ }^{12}$ The iconography of the lira da braccio is discussed in Laurence C. Witten II, "Apollo, Orpheus, and David: A Study of the Crucial Century in the Development of Bowed Strings in North Italy 1480-1580 as Seen in Graphic Evidence and Some Surviving Instruments," Journal of the American Musical Instrument Society 1 (1975), 5-55; Emanuel Winternitz, Musical Instruments and Their Symbolism in Western Art (New Haven, CT: Yale University Press, 1979), 95; and Jones, The lira da braccio, 16-28.
} 
magical sympathetic effects of music performed on instruments of various sorts. If one wishes to frighten sheep, for example, Della Porta recommends playing on a lyra "strung with Sheep strings, mingled with strings made of a Wolfs guts," since the instrument "will make no Musick, but jar, and make all discords." ${ }^{3}$ He noted further that pregnant women will miscarry if they hear music played on an instrument strung with strings made of serpents, and to fight off the plague he recommended the use of a lyra made of "no other Wood than the Vine-tree; since Wine and Vinegar are wonderful good against the Pestilence, or else of the Baytree, whose leaves bruised and smelled to, will presently drive away Pestilent contagion." 14

In each of these examples, the music performed with the instrument retains the properties of the material from which the instrument is made. As Della Porta summarized, "If we would seek out the cause of [these effects], we shall not ascribe it to the Musick, but to the Instrument, and the wood they are made of, and to the skins; since the properties of dead beasts are preserved in their parts, and of Trees cut up in their wood." 15 It would be difficult to believe that indeed Della Porta had tested all of these wondrous effects of musical instruments, but one can easily imagine the more general statements about the emotional powers of music-that music in some modes will calm the listener, while music in other modes make the listener angry, and that some music facilitates sleep while other music encourages wakefulness-being demonstrated and discussed within his academic gatherings.

By contrast, the acoustical wonders that seem to involve empirical observation through sensory experience must, by definition, have been tested. In these, Della Porta provided means for the experimenter to create sonic illusions; through deception and surprise, the magus would inspire a sense of wonder in his audience. His simplest acoustical wonder, which laid the groundwork for the development of the Aeolian harp by Athanasius Kircher, is the playing and sympathetic resonance of instruments caused by the wind. On a "tempestuous" day one may set instruments (he mentions not only the lyra but also flutes, dulcimers, and pipes) outside, such that "the wind will run violently into them, and play low [i.e., quietly] upon them... whence if you stand neer and listen, you will hear most pleasant Musick by consent of them all, and will rejoyce."16

\footnotetext{
${ }^{13 “}$ "Fides de intestinis ovium, cum fidibus de intestinis luporum permiste non concordant, sed obstrepunt." Della Porta, Magia naturalis, 299; translated in Natural Magic, 403.

14“"quod non nisi ex vitigineo ligno esse poterat, quùm mire vinum, \& acetum contra pestilentiam valeant. Vel ex lauro, cuius folia tusa, \& olfacta subinde pestilentie contagia prohibeant." Della Porta, Magia naturalis, 299; translated in Natural Magick, 404.

${ }^{15}$ "Sed si nos huius causam perscrutari velimus: non modis, sed fidibus, \& instrumentorum ligno, \& pellibus attribuemus, quùm mortuorum animalium, \& succisarum arborum etiam in membris \& lignis proprietates conserventur, ut alibi diximus in hoc libro. Et ut exempla adducamus à notissimis." Della Porta, Magia naturalis, 298-99; translated in Natural Magick, 403.

16“"advenìens enim ventus impetu ruit, leviter pulsat, \& hiantes calamos percurrit, unde ex omnium sonitu vicinis auribus suavissimum percipies concentum \& laetaberis." Della Porta, Magia naturalis, 300; translated in Natural Magick, 405. On the importance of this demonstration for the development of the Aeolian harp by Athanasius Kircher, see Thomas L. Hankins and Robert J. Silverman, Instruments and the Imagination (Princeton, NJ: Princeton University Press, 1995), 89.
} 
A more complex illusory demonstration concerns the sympathetic resonances of strings: "A harp that is play'd on, will move another harp strung to the same height. Let the strings be stretched alike, that both may come to the same melody perfectly; if you shall strike one of the base strings, the other will answer it, and so it is in the trebles." ${ }^{\prime 7}$ Even a person untrained in music could, using this method, tune an instrument if another just like it had already been prepared, for when the instruments are exactly in tune, the second set of strings will answer the first through sympathetic vibrations. If the effects of the experiment are unclear, he advised, one may place straw on top of the strings to observe their vibrations. This suggestion indicates that Della Porta encountered a disbeliever, or someone who could not tune the instrument properly using his method of sympathetic resonance, so he developed this "proof" using straw as a means of supplementing the demonstration.

The final example of Della Porta's acoustical experiments-and the one with which his section on musical magic concludes-is noteworthy for the paragone that it presents among the senses:

That a deaf person may hear the sound of the harp, or else stop your ears with your hands, that you may not hear the sound. Then take fast hold of the instrument by the handle with your teeth, and let another strike on it, and it will make a musical noise in the brain, and may be a sweeter noise. And not onely taking hold of the handle with your teeth, but the long neck, neer the Harp, and by that you shall hear the sound perfectly, that you may say that you did not hear the Musick, but taste it. ${ }^{18}$

Della Porta's magic restores sound to the deaf-or to those who wish to pretend deafness by covering their ears. It also places the musical instrument at the center of sensory experimentation, uniting the sense of hearing with that of taste. Such multisensory imaginings were essential to early modern strategies of learning and experiencing the world, and the academies constituted fertile ground for the testing and replication of these ideas. ${ }^{19}$

That Della Porta left these three experiments for the end of his section on music is noteworthy: although he did not place them into a distinct category, separate from the magic gleaned from folklore and classical sources, he seems to have recognized that these three marvels stood apart from the rest. They are based in his own observations using the senses of hearing, vision, and even taste. Indeed, in contrast to the neo-Platonist magic that dominates the majority of Della Porta's discussion of musical wonders (driving off the

\footnotetext{
17“ "Lyra, quae pulsata ealteram eiusdem toni immotam moveat. Tendantur in unum nervi, ut ad idem \& perfectum perveniat unusquisq; melos, si graium unam pulsabis digitis, altera roboat \& movetur gravis in ea, sic acutarum." Della Porta, Magia naturalis, 300; translated in Natural Magick, 405.

${ }^{18}$ "Si vero ut Lyra surdus audiat sonum Vis, vel manibus aures abde ritè, ne sonum audias, tunc capulum lyrae, vel citharae mordicus praehendito, pulset eam alter, \& concinnum in cerebro dabit sonum, \& fortasse suaviorem. Nec solum capulum dentibus captans, sed longissimam hastam, quae lyram tangat, \& per eam clarè auditur sonus, diciq'; poterit non auditus sensu, sed gustu percipere." Della Porta, Magia naturalis, 300; translated in Natural Magick, 405.

${ }^{19}$ Further on the paragone debates of the early modern era, see Cypess, Curious and Modern Inventions, ch. 1.
} 
plague with an instrument made of vine-wood, and so forth), these last three demonstrations are firmly rooted in an empirical approach. What enabled the sensory exploration codified in these last three demonstrations was Della Porta's peculiar and innovative uses of his musical instrument. In his hands, the lyra became an instrument of discovery.

\section{Della Porta's paragone of sound and sight: Acoustical instruments based on the optical model}

Della Porta was not alone in the late sixteenth century in his use of musical instruments for open-ended inquiry. Vincenzo Galilei's Dialogo della musica antica, e della moderna (1581) records Galilei's attempts to recover the elusive emotional powers of ancient Greek music; as his treatise makes clear, sensory experience was central to his work, and his musical instrument-his lute-was one of his primary means for establishing and testing his ideas. A one-time student of the music theorist Gioseffo Zarlino, Galilei largely rejected his teacher's precepts concerning the harmonic and contrapuntal construction of modern music. He did refer to ancient Greek sources on music, but he used them to justify the new systems of tuning and the new monophonic, declamatory style of singing that he advocated. Ann E. Moyer has identified Galilei's experiments on tuning and temperament, which he performed with his lute, as key to the establishment of the new field of "sounding bodies," or acoustics. ${ }^{20}$

Della Porta's slight treatment of music in the Magia naturalis cannot compare with the lengthy tomes on the subject by Galilei, which were laced with both learned mathematics and practical musical knowledge. It is clear that Della Porta approached music as an amateur, not as someone professionally trained and active as a performer, composer, and theorist. Nevertheless, his experimental demonstrations with his lyra indicate that, like Galilei, he viewed musical instruments as vehicles for the creation of knowledge.

Yet Della Porta was not a dilettante in all subjects; he was a learned expert in numerous fields, among them optics. I propose that a clearer picture of his approach to musical instruments may be gleaned from his understanding of optical instruments and their uses. An opening for an analogy between optical and acoustical instruments lies in his description of an ear trumpet,

\footnotetext{
${ }^{20}$ On Vincenzo Galilei's experimental method, see Palisca, "Scientific Empiricism in Musical Thought," in Studies in the History of Italian Music and Music Theory, 200-35; Palisca, "Was Galileo's Father an Experimental Scientist?"; $\mathrm{H}$. Floris Cohen, "Beats and the Origins of Early Modern Science," in Music and Science in the Age of Galileo, ed. Victor Coelho (New York: Springer, 1992), 17-34; Cohen, "Galileo Galilei," in Number to Sound: The Musical Way to the Scientific Revolution, 219-32; and Stillman Drake, "Renaissance Music and Experimental Science," Journal of the History of Ideas 31/4 (Oct.-Dec., 1970), 483-500. On Galilei's role in the establishment of acoustics as an area of inquiry, see Ann E. Moyer, Musica scientia: Musical Scholarship in the Italian Renaissance (Ithaca, NY: Cornell University Press, 1992), especially ch. 4, "The Science of Sound and the Study of Culture." On the formation of the field of acoustics in the seventeenth century, see Penelope Gouk, "Acoustics in the Early Royal Society 1660-1680," Notes and Records of the Royal Society of London 36/2 (Feb. 1982), 155-75, and Gouk, Music, Science, and Natural Magic, 157-92. See also Paolo Mancosu, "Acoustics and Optics," in The Cambridge History of Science, vol. 3, Early Modern Science (Cambridge: Cambridge University Press, 2006), 597-611.
} 
an invention that occupies another section of his "Chaos." Della Porta based his invention on models from nature, including a menagerie of animals with the best hearing. Ultimately, he settled on the example of the hare, and he outlined the manner in which the ear trumpet could best be configured to replicate this living model. In presenting this acoustical wonder, Della Porta drew an analogy between this instrument of sound and the many optical instruments - spectacles, mirrors, magnifying glasses, and other catoptric or illusory lenses-that he had described in Book 17 of the Magia naturalis: "In my Opticks I shewed you Spectacles, wherewith one might see very far. Now I will try to make an Instrument, wherewith we may hear many miles." $\mathrm{He}$ repeated this analogy at the end of his discussion, advising the reader to "Fit your instrument to put into your ear, as Spectacles are fitted to the eyes." 21

As Matteo Valleriani has shown, Della Porta's formulation was apparently the first of many statements from the late sixteenth and early seventeenth centuries that saw the nascent field of acoustics as integrally connected with that of optics; indeed, it was this model that was taken up by Galileo Galilei and his one-time student Paolo Aproino in their attempts, soon after the publication of the Siderius nuncius, to invent their own ear trumpet based on their experimental work. Yet, as Valleriani suggests, Galileo and Aproino abandoned this project because they lacked the theoretical apparatus to explain it. The field of acoustics was still in transition from the Aristotelian understanding to a mechanical conception "based on the analogy between optics and acoustics," and Galileo was not yet able to present his invention with a fully formulated explanation of why it worked as efficiently as it did. Nevertheless, Della Porta's statements comparing the ear trumpet to eyeglasses suggest that on an abstract level, instruments of sound and instruments of sight were already considered analogous. And, as an extension of this analogy, it seems significant that Galileo's method for the construction of his telescope involved the appropriation of an organ-pipe for use as the tube separating the lenses. ${ }^{22}$

If Della Porta's knowledge of the mathematical principles underlying acoustics and music was limited, his optical knowledge was quite advanced, as shown not only by his extensive treatment of catoptric lenses in Book 17 of the Magia naturalis but also by his Latin treatise De refractione (1593). The link that he forged between spectacles and the ear trumpet is thus entirely appropriate: it enabled him to refer the reader back to his earlier work in an

\footnotetext{
21"In opticis specilla demonstravimus, quibus fatis longè videre poteramus, nunc instrumentum construere tentabimus, quo etiam per multa miliaria audire possimus." "Accommodetur igitur instrumentum, ut commodè auribus indatur, ut specilla oculis." Della Porta, Magia naturalis, 296-97; translated in Natural Magick, 400-401.

${ }^{22}$ Matteo Valleriani, "Galileo's Abandoned Project on Acoustic Instruments at the Medici Court," History of Science 1 (2012), 1-31; see also Valleriani, Galileo Engineer (Dordrecht, The Netherlands: Springer, 2010), 43-44. Valleriani argues that Galileo was reluctant to present an invention for which he lacked a theoretical explanation, since such an approach would have undermined his claim to the status of "philosopher" rather than "engineer" or "mathematician." This understanding of Galileo's professional trajectory is based on Mario Biagioli's foundational work on the social contexts of early modern science in Galileo, Courtier (Chicago: University of Chicago Press, 1993).
} 
area in which he possessed greater expertise. Taking a cue from this link between sight and sound, I will consider Della Porta's playful yet exploratory approach to optical instruments within the Magia naturalis as a model for understanding his musical and acoustical experimentation.

Book 17 of the Magia naturalis celebrated the playful trickery involved in the science of "catoptrics"-illusion-producing lenses. Mirrors, crystals, and glasses of various shapes-all of which were understood as members of a single category of instruments-carried the potential to clarify the viewer's perception, to distort it, and to multiply it. In his introduction to this section of his work, Della Porta emphasized both the playfulness of optical illusions and the benefits that they could produce:

Now I am come to Mathematical Sciences, and this place requires that I shew some experiments concerning Catoptrick glasses. For these shine amongst Geometrical instruments, for Ingenuity, Wonder, and Profit: For what could be invented more ingeniously, then $[\mathrm{sic}]$ that certain experiments should follow the imaginary conceits of the mind, and the truth of Mathematical Demonstrations should be made good by Ocular experiments? ${ }^{23}$

He laid out a long inventory of wonders that may be effected by means of such instruments. Using mirrors and variously shaped reflecting lenses, he offered the reader the means to create distorted or inverted images of familiar objects, to conjure apparent "phantasms" that seem to "hang in the air," and other "merry sports." These experiments must have been tested in Della Porta's academic gatherings; after the publication of the Magia naturalis, he continued to perform these same optical demonstrations for such esteemed visitors as Federico Cesi, and they constituted the basis for Della Porta's first entrée into Cesi's Accademia dei Lincei. In Della Porta's understanding, instruments used and positioned in specific, playful ways may inspire a sense of wonder at the variety of nature and the human senses. ${ }^{24}$

If the trickery of the Magia naturalis makes Della Porta's approach to optics seem less than serious, this appearance is belied by the Latin treatise De refractione optices, which he published in 1593. Although, as Sven Dupré has shown, this work lacked the systematic proofs that would characterize the next generation of scientific writing, the volume was aimed at an audience of

\footnotetext{
23"Iam ad mathematicas scientias deventum est, exigit locus, ut catoptrica tradantur experimenta, renident enim inter Geometrica ingeniositate, mirabilitate, utilitatq'. Quid enim ingeniosius excogitari potuit, ut imaginarijs animi conceptionibus certissima experimenta sub sequerentur?" Della Porta, Magia naturalis, 259; translated in Natural Magick, 355.

${ }^{24}$ On the subject of images "hanging in the air," see Sven Dupré, "Inside the Camera Obscura: Kepler's Experiment and Theory of Optical Imagery," Early Science and Medicine 13 (2008), 223-31. For more on the early seventeenthcentury shifts in the science of optics, see Vincent Ilardi, Renaissance Vision from Spectacles to Telescopes (Philadelphia: American Philosophical Society, 2007), 207-52. Della Porta's testing of his experiments within an academic environment is discussed in William Eamon, "Science and Popular Culture in Sixteenth-century Italy: The 'Professors of Secrets' and Their Books," The Sixteenth-century Journal 16/4 (Winter 1985), 478; and his use of optical experiments as a means of gaining entrance into the Lincei is discussed in Findlen, Possessing Nature: Museums, Collecting, and Scientific Culture in Early Modern Italy (Berkeley: University of California Press, 1994), 229-30.
} 
educated mathematicians. In it, Della Porta put forth his views on the workings of the eye and of optical lenses, and he would later claim that this treatise featured a model of the telescope that prefigured Galileo's. ${ }^{25}$

Tomaso Garzoni's widely circulated Piazza universale di tutte le professioni del mondo, first published in 1585 and issued in numerous editions and reprints in the ensuing decades, constitutes an important source on the understanding of optical instruments in the late sixteenth century, and on the place of a magus such as Della Porta in the dissemination of knowledge. Garzoni described the wondrous effects of lenses and the practitioners of the art of lens-making. While tracing the origins of this profession to the science of optics, and relating its importance for the technical work of Aristotelian writers on optics, Garzoni identified "speculari, et specchiari" as a distinct profession. He wrote of the stupor that may be inspired by the images produced by lenses and mirrors, making special note of the illusions they could produce:

The origin of the science of lenses ... derives from nothing else than the miraculous effects [that may be] seen and considered through lenses, which enable one to see the image of visible objects in numerous and varied ways. And it shows infinite hidden images, from which is generated that part of [the field of] perspective that was called "catoptrics" by the Latins and Greeks. [This field] is of such miraculous value, because it presents reasons for many beautiful images that may be seen in lenses, as a result of which the world is often filled with stupor. ${ }^{26}$

Beyond connecting catoptrics with optics and perspective, Garzoni emphasized the usefulness of lens-making for other fields as diverse as theology and natural philosophy. Of its role in astrologia (astronomy), the Piazza related that lens-making may "resolve many questions regarding celestial things, such as, for example, the spots on the moon, and eclipses, and the projection of rays." 27 And he noted the ability of optical illusions to elicit emotional responses in the viewer, repeatedly using the terms stupor

\footnotetext{
${ }^{25}$ Della Porta's treatise on optics was published as Giovanni Battista Della Porta, De refractione optics parte. Libri novem (Naples: lo. lacobum Carlinum, 1593). On aspects of his theories of optics discussed here, see David C. Lindberg, Theories of Vision from Al-Kindi to Kepler (Chicago: University of Chicago Press, 1976), 182-85; Fumikazu Saito, "Perception and Optics in the 16th Century: Some Features of Della Porta's Theory of Vision," Circumscribere 8 (2010), 29; Sven Dupré, "Visualization in Renaissance Optics: The Function of Geometrical Diagrams and Pictures in the Transmission of Practical Knowledge," in Transmitting Knowledge: Words, Images, and Instruments in Early Modern Europe, ed. Sachiko Kusukawa and lan Maclean (Oxford: Oxford University Press, 2006), 33; and Freedberg, The Eye of the Lynx, 101-05. On Della Porta's apparent desire for secrecy concerning his ideas of telescopic lenses, see Reeves, Galileo's Glassworks, 72-77.

${ }^{26}{ }^{2}$ 'origine della scienza de' specchi...è derivata non altronde, che dai miracolosi effetti visti, e considerati ne' specchi, facendo eglino vedere in tanti, e cosi varij modi l'imagini de gli obietti visibili, \& mostrando infinite apparenze oblique, dalle quali è generata quella parte di prospettiva, che specularia si dimanda da' Latini, \& da' Greci catoptrice, il cui pregio è mirabile, perche ella ne rende la cagione di tante belle apparenze, che ne gli specchi si veggono, per le quali il mondo sovente s'empie di stupore." Thomaso Garzoni, Piazza universale di tutte le professioni del mondo ... aggiuntovi in questa nuova impressione alcune bellissime annotationi a discorso per discorso (Venice: Roberto Meglietti, 1586), 896.

27“... per dar risolutione di molte questioni nelle cose celesti, come verbi gratia della macchia della Luna, dell'ecclissi, \& della proiettion de' raggi." Garzoni, Piazza universale, 896.
} 
and meraviglia in describing them, and remarking even that they had the capacity to make distant friends appear present. ${ }^{28}$

Above all, Garzoni described the many kinds of images-real and illusory, accurate and distorted - that may be produced by lenses, and he celebrated the variety that they produced: the "infinite effects that various lenses present to the eye." ${ }^{29}$ He recounted classical and contemporary tales that attest to the magic of mirrors, glass, water, prisms - transparent and reflective lenses of all types. His account of the tale of Narcissus is perhaps especially telling, for, as Paula Findlen has suggested, the story of Narcissus represented the illusion and play inherent in the visions produced by nature. The early modern fascination with Ovid's Metamorphoses as a whole emphasized the variety and variability in the world and in the self. In the story of Narcissus, and in the world of neo-Platonist magic as a whole, "It appeared that nature was constantly in flux, always in the process of becoming something else.... The scientific playfulness of mirrors was a conscious attempt to rewrite the fable of Narcissus, blending 'poetic fiction' and scientific fact." ${ }^{\text {"30 }}$

Garzoni's Piazza universale played an essential role in the dissemination of knowledge about popular science. Directed at a wide-ranging audience, this work synthesized information from a vast array of sources-learned, popular, reliable, deceitful-and presented it in a new amalgam. For "virtuosi" eager to collect scientific instruments, perform the experiments, and compile the recipes put forth by Garzoni's "professors of secrets," the Piazza universale offered a point of access to work in advanced, learned areas such as optics. The field of catoptrics seems to have offered just the right balance between scholasticism (its roots went back to the ancients, and it could be read about in contemporary treatises), experience (it could be practiced and repeated in the context of courtly and academic gatherings), and play (it delighted the onlooker and helped to "distinguish one's ability to read a joke, to get the trick" ${ }^{\prime 1}$ ). For, as Horst Bredekamp has suggested, playfulness at the intersection of nature and art was an essential component of early modern science. ${ }^{32}$

Among the "professors of secrets" whom Garzoni cited was none other than Della Porta. And the purposes of such secrets, as Della Porta informed his reader, were both practical and aesthetic. Their usefulness lay, for example, in enabling spies to see far away, in creating the illusion of a large army

\footnotetext{
$28 "$. .. scoprissero il suo concetto a gli amici distani da lui molte migliaia di miglia." Garzoni, Piazza universale, 898.

29“. ..quanto son infiniti gli effetti, che i diversi specchi producono all'occhio." Garzoni, Piazza universale, 901.

${ }^{30}$ Paula Findlen, "Jokes of Nature and Jokes of Knowledge: The Playfulness of Scientific Discourse in Early Modern Europe," Renaissance Quarterly 43/2 (Summer 1990), 312, 322.

${ }^{31}$ Findlen, "Jokes of Nature," 321. See also William Eamon, The Professor of Secrets (Washington, DC: National Geographic Society, 2010), 198-203.

${ }^{32}$ On the significance of the Piazza universale, see George W. McClure, The Culture of Profession in Late Renaissance Italy (Toronto: University of Toronto Press, 2004), ch. 3, "Shuffling the Deck: Tomaso Garzoni's Universal Piazza of all the Professions of the World"; Garzoni's "professors of secrets" are discussed in William Eamon, Science and the Secrets of Nature (Princeton, NJ: Princeton University Press, 1994), 134-67. On a playful approach to the study of the relationship between art and nature, see Bredekamp, The Lure of Antiquity and the Cult of the Machine, 69-80.
} 
where only a small one existed, or simply in making a small object more easily visible. In addition, though, Della Porta, Garzoni, and numerous other writers on catoptric lenses remarked on the novelty of such instruments and the sense of meraviglia they could inspire. Thus when Galileo wrote in 1610 to Belisario Vinta, an adviser to the Grand Duke Cosimo I de' Medici, of the marvelous effects of his telescope, his description resonated with a long tradition of reception and understanding of optical marvels:

I am at present in Venice, to have printed some observations that I have made by means of one of my lenses [occhiale] of the celestial bodies, and just as they are of infinite stupor, so infinitely do I render thanks to God, who has seen fit to make me alone the first observer of a thing so admirable, and held secret [occulta] throughout the centuries. ${ }^{33}$

Years before the invention of the powerful and technically advanced telescope that Galileo used to view the Medicean stars, optical instruments were seen as a means for inspiring wonder through the sense of sight. ${ }^{34}$ Galileo's open-ended inquiry with his telescope represented a continuation of the exploration undertaken with lenses by Della Porta and others of his generation.

\section{Magic seen, magic heard}

Garzoni's Piazza universale is an enormous tome. It is not surprising, therefore, that he treats music as well as optics, and, indeed, he noted the presence of music in both nature and art, repeating the ancient wisdom-ubiquitous in Renaissance music theory-concerning the so-called harmony of the spheres and the music inscribed in the creation of the earth: "there is nothing in the world made without geometry and music."35

Beyond this homage to the ancient sources, however, Garzoni advocated another approach to music-making-one based in practical experience with instruments. His section on the profession of music-making bears a title that makes a special case for the inclusion of instrumentalists alongside singers: "De musici cosi cantori, come suonatori, \& in particolare de' pifferi" (Of musicians, both singers and players, and in particular wind-players"). ${ }^{36}$ He offered precedents for this approach, listing names of dozens of classical

\footnotetext{
33"Io mi trovo al presente in Venezia per fare stampare alcune osservazioni, le quali col mezzo d'un mio occhiale ho fatte nei corpi celesti, e siccome sono d'infinito stupor, così infinitamente rendo grazie a Dio, che si sia compiaciuto di far me solo primo osservatore di cosa così ammiranda, e tenuta a tutti i secoli occulta." Galileo to Belisario Vinta, 30 January 1610. Transcribed in Le opere di Galileo Galilei, 15 vols., ed. Eugenio Albèri and Celestino Bianchi (Florence: Società Editrice Fiorentina, 1847), 6:81.

${ }^{34}$ See Albert Van Helden, "The Invention of the Telescope," Transactions of the American Philosophical Society 67/4 (1977), 1-67. On Galileo's activities as a lens-maker and their relationship to his telescopic observations, see Eileen Reeves, Galileo's Glassworks, and Valleriani, Galileo Engineer, 41-66.

$35 "$...non è cosa al mondo fatta senza geometria, \& musica." Garzoni, Piazza universale, 445.

36" Pifferi" might refer to wind players in general or to players of the cornetto, an instrument that had achieved special recognition in the late sixteenth century for its difficulty and its especially beautiful sound. See Bonnie
} 
figures who had attained facility at a musical instrument, and he followed these names with a list of contemporary musicians whom he deemed worthy of recognition-not singers, but instrumentalists, artisans - and who served as evidence of the value of the profession of music. It was the practice of this profession, not merely its theory, that Garzoni advocated. ${ }^{37}$

This is precisely the approach that Della Porta took to his experimentation with musical instruments. An amateur rather than a professional, Della Porta approached his lyra with the same sense of curiosity and wonder that he applied to his optical instruments. Like Vincenzo Galilei, he put musical instruments to use in inventive ways. Whereas Galilei sought a reform in the professional understanding of music and the science of sound, Della Porta used his instrument to create playful sonic illusions that would astonish onlookers and listeners.

What can we learn about Della Porta's approach to musical instruments through consideration of his approach to optical instruments? The first lesson, I propose, lies in the aesthetics of meraviglia that informed the approaches of Della Porta, Garzoni, and their contemporaries: in calling attention repeatedly to the "wonder" aroused in the viewer at the ability of the instrumentalist to conjure the "imaginary conceits of the mind," Della Porta's description turned the act of demonstration into a performance and equated its effect on the viewer with that inspired by the experience of an artwork. This sense of meraviglia underlies Della Porta's approach to musical instruments as well: he wrote that his demonstrations and pieces of wisdom on the effects of musical instruments would cause the listener-observer to "rejoyce," reveling in the power of musical magic.

Another point to be gleaned from the juxtaposition of Della Porta's treatments of optical and acoustical experimentation is their relationship to the learned fields from which they emerged. Della Porta was an expert in optics; his extensive catalogue of natural magic in catoptrics is based on this knowledge, but it is directed at the letterati and virtuosi of science. Although Della Porta lacked the strong theoretical knowledge of music that may be seen in the writings of Vincenzo Galilei, he nevertheless recognized a place for acoustical experimentation within academies populated by gentlemenamateurs. That Della Porta's understanding of musical instruments is heavily informed by his neo-Platonist approach underscores the close connection between natural magic, science, and the arts in the early modern era.

Most importantly, however, Della Porta approached musical instruments in the open-ended manner that characterized his approach to optical instruments. In his section on catoptrics, Della Porta emphasized the novelty of his

Blackburn and Edward E. Lowinsky, "Luigi Zenobi and His Letter on the Perfect Musician," Studi Musicali 22 (1993), 61-107.

${ }^{37}$ Garzoni, Piazza universale, 441-53. 
demonstrations, and he invited the reader to join in the process of invention: "Though venerable Antiquity seems to have invented many and great things, yet I shall set down greater, more Noble, and more Famous things, and that will not a little help to the Optick Science, that more sublime wits may increase it infinitely." ${ }^{38}$

With the lira da braccio institutionalized as a fixture within numerous Italian academies, it was the instrument most readily available to the amateur practitioners of science and natural magic to whom Della Porta's treatise was directed. In describing his three experimental demonstrations, Della Porta showed that unusual uses of the lyra could reveal new information about the behavior of sound and the interrelationship of the senses. These demonstrations also provided a model for further trial with instruments, encouraging their use in the quest for new knowledge.

More than thirty years after the expanded edition of Della Porta's Magia naturalis appeared in print, Francis Bacon remarked in his Novum organum (1620) on the importance of artisanship in the new system of knowledge that he was building. To gain new understandings of nature, he asserted, the philosopher should seek out all he could from both nature and art, including objects and processes that seemed exceptional or even unique. He wrote,

The better kinds of artificial materials are surely those which either most closely imitate nature, or on the other hand masterfully rule her and turn her upsidedown. Again, among the contrivances and tools of man, we should not condemn [juggling] tricks and toys [praestigiae et jocularia] out of hand. Their applications are trivial and frivolous, but some of them may be useful for information. ${ }^{39}$

The curiosities that Della Porta collected and the illusions that he sought to produce through performance of his demonstrations and experiments may surely be classified among the "contrivances and tools of man." Yet Bacon recognized that even this kind of magic had a place in the new science. Della Porta's playful, exploratory, and innovative approach to instruments-his praestigiae et jocularia-helped to spread knowledge and ideas.

\footnotetext{
38“"Et si multa \& magna veneranda antiquitas excogitaße visa est; nos maiora, augustiora, illustrioraq' trademus, nec parùm ad opticam scientiam aspirantibus profutura, ut sublimiora ingenia in infinitum eapossint propagare." Della Porta, Magia naturalis, 260; translated in Natural Magick, 355.

39"Atque praeferenda sane sunt in artificialibus ea quae maxime accedunt ad imitationem naturae, aut e contrario eam potenter regunt et invertunt. Rursus, inter ingenia et manus hominis, non prorsus contemnenda sunt praestigiae et jocularia. Nonnulla enim ex istis, licet sint usu levia et ludicra, tamen informatione valida esse possunt." Bacon, Novum organum, 2:31. Translation adapted from Francis Bacon, The New Organon, ed. Lisa Jardine and Michael Silverthorne, Cambridge Texts in the History of Philosophy (Cambridge: Cambridge University Press, 2000), 152, emphasis added.
} 